\title{
Associations between macrobenthos and invasive cordgrass, Spartina anglica, in the Danish Wadden Sea
}

\author{
Min Tang • Erik Kristensen
}

Received: 12 December 2008 / Revised: 5 December 2009 / Accepted: 22 December 2009 / Published online: 5 January 2010

(C) Springer-Verlag and AWI 2010

\begin{abstract}
We conducted a survey to provide knowledge on mechanisms controlling spatial and temporal variability of macrobenthos in an intertidal Wadden Sea area partly covered by invasive Spartina anglica. Benthic macrofauna was collected seasonally at seven stations along a transect covering non-vegetated mudflat and vegetated marsh areas. Shannon diversity index was consistently higher for macrobenthos in the open mudflat compared to the marsh area. Infaunal species, like Arenicola marina, Tubificoides benedeni and Macoma balthica, were more abundant in the mudflat than the marsh, while the opposite was evident for epifaunal species, like Hydrobia ulvae and Littorina littorea. The infaunal crustacean, Corophium volutator, on the other hand, appeared particularly attracted to the mudflatmarsh boundary. The biomass of below-ground plant materials and macrodetritus was positively correlated with the total macrofaunal abundance, while the biomass of dead below-ground plant materials alone showed a significant negative correlation with infaunal abundance. Total macrofaunal abundance was highest during summer in the mudflat, while no seasonal pattern was evident in the marsh.
\end{abstract}

Communicated by Luis Gimenez.

Electronic supplementary material The online version of this article (doi:10.1007/s10152-009-0187-2) contains supplementary material, which is available to authorized users.

\section{Tang $(\bowtie) \cdot$ E. Kristensen}

Institute of Biology, University of Southern Denmark, 5230 Odense M, Denmark

e-mail: cxtangmin@yahoo.com

\section{Tang}

Key Laboratory of Tropic Biological Resources of Ministry of Education, Faculty of Material and Chemical Engineering, Hainan University, 570228 Haikou, China
The negative influence of S. anglica invasions on infaunal abundance may have serious implications for higher trophic levels, such as waterbirds, that forage in Wadden Sea areas and thus for the overall biodiversity and ecosystem functioning.

Keywords Danish Wadden Sea · Invertebrate macrobenthos $\cdot$ Seasonal variation $\cdot$ Spartina anglica . Non-parametric multidimensional scaling

\section{Introduction}

Invertebrate macrobenthos are an integrated biological component in intertidal soft-sediment ecosystems including mudflats, sandflats and saltmarshes (Snelgrove 1998; Levin and Talley 2000). Macrobenthos modify topographical features, affect sediment stability, controls energy flow and nutrient cycling and also influences the meiofauna and microorganisms (Aller and Aller 1998; Snelgrove 1998; Reise 2002). Most macrofauna are also of great importance to ecological- and economic-important species at higher trophic levels (Reise 2005; Rosa et al. 2008). Provided the significant roles and feasibility for experimental analysis, macrofauna assemblages are generally regarded as important indicators of system resilience to disturbances, such as biological invasions, pollution and eutrophication (Snelgrove 1998; Levin and Talley 2000). The accelerating concerns on bioinvasions in coastal soft-sediments have inspired much recent research (Reise et al. 1999, 2006; Thieltges et al. 2006; Cottet et al. 2007; Nehring and Hesse 2008).

Spartina anglica and Spartina alterniflora are widely spread invasive species with significant ecosystem-engineering impacts along many intertidal coasts and estuaries 
throughout the world (e.g. Hacker et al. 2001; Cottet et al. 2007). Much work has been undertaken on the changes of invertebrate macrobenthic assemblages associated with Spartina saltmarshes in North America (Levin and Talley 2000; Neira et al. 2005; Brusati and Grosholz 2006), while there is only limited information from northern Europe (Vinther et al. 2001; Gribsholt and Kristensen 2003). The Wadden Sea is treasured by its special native biodiversity and is a stepping stone for a variety of migratory waterbirds (Vinther et al. 2001; Loebl et al. 2006). S. anglica was introduced in the Danish Wadden Sea around 1,940 where no native Spartina species were present (Nehring and Hesse 2008). Since then, meadows and scattered tussocks of $S$. anglica have been common features in many intertidal parts of the Danish Wadden Sea. The ecological consequences of this robust halophyte invasion remain largely unexplored in this area (Nehring and Hesse 2008).

The purpose of this study was to evaluate temporal and spatial variation of invertebrate macrobenthic assemblages in relation to the presence of $S$. anglica. We hypothesize that $S$. anglica vegetation prevents the development of infaunal populations due to the dense mass of roots and rhizomes. Epifauna should be much less affected and could be promoted by the large surface area provided by the plants. Since there is little knowledge on this subject from the Danish Wadden Sea, this study should be considered pioneering work that provides knowledge for further research on the impact of Spartina invasions.

\section{Materials and methods}

The study site $\left(55^{\circ} 17.8^{\prime} \mathrm{N}, 8^{\circ} 39.2^{\prime} \mathrm{E}\right)$ is situated near the town of Vester Vedsted in the Danish Wadden Sea (Fig. 1). Artificially controlled accreting salt-marsh areas dominate the upper semi-sheltered coastline. These marshes consist of depositional compartments (about $200 \mathrm{~m} \times 200 \mathrm{~m}$ ) separated by low $(\approx 1 \mathrm{~m}$ high) wooden fascine fences that face the dikes and protect the hinterland. The tide is semi-diurnal with an average tidal amplitude of about $2.0 \mathrm{~m}$. Water temperature and salinity ranged seasonally from 2 to $14^{\circ} \mathrm{C}$ and 25 to 28 , respectively. Tidal water enters and exits each compartment through a $20-\mathrm{m}$ wide opening. The dominant macrophyte Spartina anglica $(<0.6 \mathrm{~m}$ tall) forms a continuous meadow at the landward part of the compartments, with patches of different size scattered at the seaward fringe of the marsh. There are no creeks and erosion cliffs at the studied marsh site. The dominating species among other marsh plants are Salicornia europaea, Puccinellia maritima, Suaeda maritima, Spergularia maritima, Aster tripolium, Triglochin maritima and Plantago maritima.

One representative transect (about $190 \mathrm{~m}$ long) consisting of seven sampling stations (St. A-G) was established in the centre of a fascine compartment next to the ebb road leading to the island of Mandø. The stations at the open mudflat (St. A-D) were about $40 \mathrm{~m}$ apart, while those in the S. anglica marsh (St. E-G) were about $17 \mathrm{~m}$ apart. All stations in the transect were situated at a similar tidal level, and the daily exposure time differed less than $20 \mathrm{~min}$ between St. A and St. G.

Triplicate sediment cores (20-25 cm deep) for biotic parameters were collected at each station during daytime low tide period using a steel corer $(15.0 \mathrm{~cm}$ i.d., $30.0 \mathrm{~cm}$ high) in May 2006, September 2006, January 2007 and March 2007. The sample inside the corer included the overlying vegetation, sediment, detritus and all macrofauna (epifauna and infauna). The samples were immediately sieved (1-mm mesh) in the field, and all macrofauna, Spartina material, macrodetritus (unidentifiable organic particles retained on the 1-mm sieve screen) and gravel, were

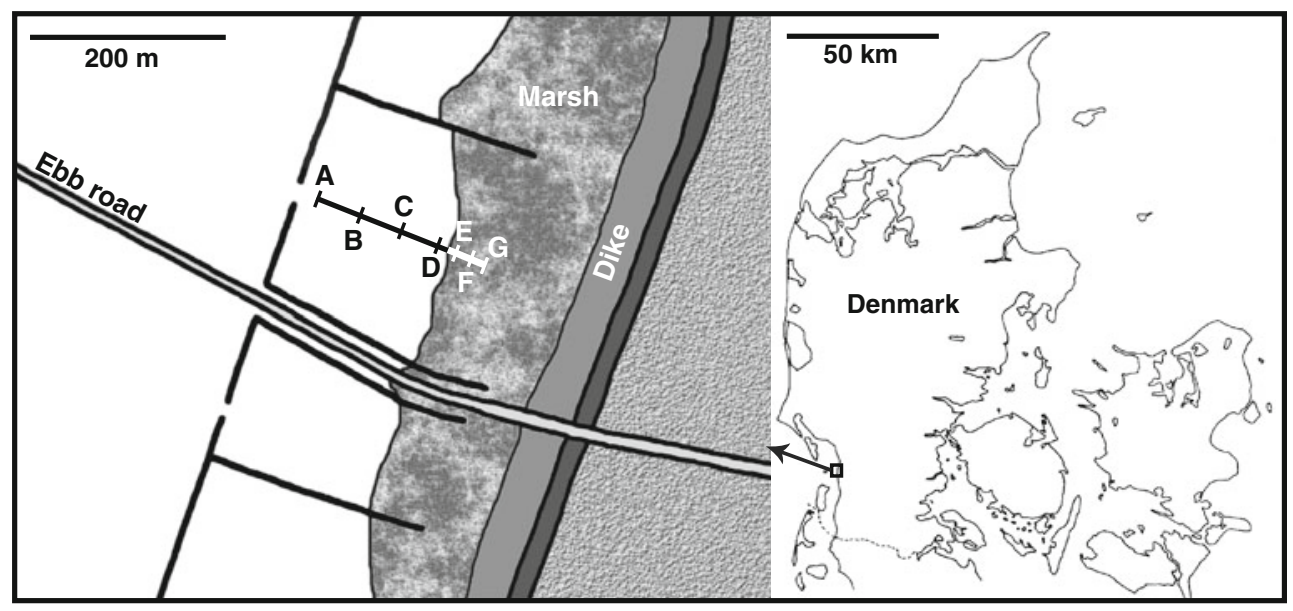

Fig. 1 Map of the study site at the south-western coast of Jutland, Denmark. The examined transect is shown with stations indicated by letters 
preserved in $80 \%$ ethanol for later sorting and analysis in the laboratory. The Spartina material was carefully divided into four categories according to Netto and Lana (1999): live above-ground, dead above-ground, live below-ground, dead below-ground. The Spartina materials and macrodetritus were dried to constant weight at $80^{\circ} \mathrm{C}$ to determine biomass. Specimens of macrofauna were identified to the lowest possible taxon, usually to the species level, under a dissection microscope. The macrofauna of each sample was enumerated into taxonomic groups, and the biomass of macrobenthos was determined after drying at $100^{\circ} \mathrm{C}$ for $24 \mathrm{~h}$.

Sediment properties were examined from duplicate sediment cores ( $5.2 \mathrm{~cm}$ i.d., $15 \mathrm{~cm}$ deep) taken as close to the location of the biological samples as possible on selected sampling occasions. Water content, organic content and Chlorophyll $a(\mathrm{Chl} a)$ concentration were measured in the top $2 \mathrm{~cm}$ of the sediment in May 2006, January 2007 and March 2007. Water content of sediment was determined as weight loss after drying at $105^{\circ} \mathrm{C}$ for $6 \mathrm{~h}$. Organic content was estimated on the dry sediment as loss of ignition (LOI) at $550^{\circ} \mathrm{C}$ for $6 \mathrm{~h}$. Chl $a$ concentration was quantified by the standard spectrometric method (Parsons et al. 1984) modified for sediment samples. Sediment grain size distribution at each station was obtained from wet sieving through a Wentworth series of sieves $(1,000,500,250,125$ and $63 \mu \mathrm{m}$ ) in January 2007. Temperature (air and water) and salinity of overlying water were monitored at each sampling occasion.

Two-way ANOVA with a posteriori Holm-sidak tests (Sigmastat 3.5) was used to test the significance of temporal and spatial differences in total and relative abundance of benthic macrofauna, sediment properties (only the data of May 2006, January 2007 and March 2007), biomass of Spartina materials and macrodetritus along the transect. All fraction and percentage data were arcsine and squareroot transformed, while the other data were logarithmic transformed when necessary. Non-parametric tests were used when transformed data did not follow a normal distribution.

The similarity of fauna assemblages and relationships among sampling stations were mapped by ordination using non-parametric multidimensional scaling (MDS) based on Bray-Curtis similarity indices. Significance testing and pairwise comparisons among different stations and sampling periods were examined using analysis of similarities (ANOSIM). Species contributions to dissimilarity between sites were determined by using similarity percentages (SIMPER). Possible relationships between fauna and environmental variables were explored using the BEST method. MDS, SIMPER, ANOSIM and BEST analyses were conducted using the PRIMER ver. 6 package (Clarke and Ainsworth 1993).

\section{Results}

The sediments along the transect in both the open mudflat and marsh areas consisted of well-sorted fine sand with a mean grain size ranging from 178 to $193 \mu \mathrm{m}$ with no apparent difference among stations. The silt and clay fraction $(<63 \mu \mathrm{m})$ accounted for $<1 \%$, except for St. A $(1.3 \%)$ and $\mathrm{B}(2.0 \%)$, and organic content (LOI) varied from 0.3 to $1.2 \%$ with highest values at St. E $(P \leq 0.001)$ (additional data are given in Online Resource, Table 1). There was a general trend for higher LOI in May 2006 and March 2007 than in January 2007 at all stations $(P \leq 0.001)$. Chl $a$ concentrations varied from 3.9 to $12.1 \mu \mathrm{g} / \mathrm{g}$ ww with the highest values at St. G and lowest at St. A, and Chl $a$ showed higher values in May 2006 and March 2007 than in January $2007(P=0.046)$. Both the depth-integrated LOI and Chl $a$ concentration in the top $2 \mathrm{~cm}$ were higher at St. E and G, than mudflat stations and St. $\mathrm{F}(P \leq 0.001)$ (additional data are given in Online Resource, Table 1).

Live and dead S. anglica materials were only found at St. E, F and G (additional data are given in Online Resource, Table 2). The live above-ground biomass at these stations ranged from 0 to $98 \mathrm{~g} \mathrm{~m}^{-2}$ and accounted for $0-26 \%$ of the live below-ground biomass. The live biomass was, in most cases, within the same order of magnitude as the dead biomass $(0.24<$ live/dead $<3.19)$. Exception were St. F and $\mathrm{G}$ where the below-ground live biomass exceeded the dead biomass by about an order of magnitude (live/ dead $=7.46-12.09$ ) in January and September, and January and March, respectively, St. F in May and March where no or very limited live biomass was recorded (live/dead = $0-0.1$ ), and St. E in March where almost no live above-ground biomass occurred (live/dead $=0.05$ ). Both above-and below-ground biomass was generally higher at St. G and $\mathrm{E}$ than $\mathrm{F}(P \leq 0.01)$. The live biomass was higher in September than January, March and May, and the dead biomass showed no seasonally significant difference $(P \leq 0.01)$. Overall, the plant biomass was higher at St. G and E, than at St. F (additional data are given in Online Resource, Tables 2 and 3).

The amount of macrodetritus increased from St. A to D and remained higher within the vegetated stations $(\mathrm{E}, \mathrm{F}$ and G, Table 1) than St. A, B and C $(P \leq 0.01)$. The average amount was higher in January than May and September $(P \leq 0.01)$.

A total of 20 macroinvertebrate species (14 infaunal and 6 epifaunal taxa) were found throughout the sampling period, including eight polychaetes, one oligochaete, five crustaceans, two gastropods, three bivalves and one nemertean. Species with very low and scattered abundance (i.e. the polychates Harmothoe spp. and Capitella capitata as well as one unknown amphipod and one nemertean) and 
Table 1 Spatial and temporal difference in biomass of plant materials and macrodetritus

\begin{tabular}{lll}
\hline & Time & Station \\
\hline Live above-ground & $9>(3,1,5) ; 5>(3,1)$ & G $>$ E, F; E $>$ F \\
Dead above-ground & NS & G $>$ (E, F); E $>$ F \\
Live below-ground & $9>(3,1,5)$ & $(\mathrm{G}, \mathrm{E})>\mathrm{F}$ \\
Dead below-ground & $\mathrm{NS}$ & $\mathrm{E}>(\mathrm{F}, \mathrm{G}) ; \mathrm{G}>\mathrm{F}$ \\
Detritus & $(1,3)>5 ; 1>9$ & $(\mathrm{D}, \mathrm{F}, \mathrm{E})>$ \\
& & $(\mathrm{A}, \mathrm{B}, \mathrm{C}, \mathrm{G}) ; \mathrm{G}>$ \\
& & $(\mathrm{A}, \mathrm{B}, \mathrm{C}) ; \mathrm{C}>\mathrm{A}$ \\
\hline
\end{tabular}

Logarithm-transformed data were analysed by two-way ANOVA with a posteriori Holm-Sidak tests. Significance level was $P \leq 0.01$. ">" represented significantly greater, while the comma means no significant difference. The sampling month is indicated by month number

$N S$ no significant difference

three highly mobile epifaunal crustaceans (Carcinus maenas, Crangon crangon Gammarus spp.) were excluded from the data analysis. Species richness (based on the 13 quantifiable species) was dominated by infauna in both the open mudflat (St. A-D) and S. anglica marsh (St. E-G; Table 2). Two infaunal species, Heteromastus filiformis and Scoloplos armiger, were absent near and within the marsh area and only appeared in the mudflat at St. A and B. The remaining species were found in various abundances in both the open mudflat and marsh areas. Shannon diversity index was consistently higher in the open mudflat (St. A-D) compared to the marsh area (St. E-G) in the four sampling seasons (Fig. 2).

Infauna was significantly more abundant and with a higher biomass in the mudflat than the marsh area, while the opposite was evident for epifauna (Fig. 3). Arenicola marina occurred with a seasonal average density of 200 300 ind $\mathrm{m}^{-2}$ at open mudflat, while only a few individuals were recovered near and within the marsh, and this species was not found at St. G at all (Fig. 4). The average weight of A. marina individuals, however, decreased from 134 to $29 \mathrm{mg} \mathrm{dw}$ from St. A to D across the mudflat. Pygospio elegans showed no significant difference in the seasonal average abundance between the mudflat and the marsh area (range 600-1,300 ind $\mathrm{m}^{-2}$ ), except for low abundance at St. E $\left(240\right.$ ind $\left.\mathrm{m}^{-2}\right)$. The average individual weight of $P$. elegans varied from 0.7 to $1.9 \mathrm{mg} \mathrm{dw}$ with no specific spatial pattern. The seasonal average abundance of Tubificoides benedeni was high at the mudflat, 1,700-2,200 ind $\mathrm{m}^{-2}$ at St. A and C, and 600-900 ind $\mathrm{m}^{-2}$ at St. B and D. This species was almost (St. F and G) or completely (St. E) absent from the marsh area. The average individual biomass of T. benedeni was $0.1-0.3 \mathrm{mg} \mathrm{dw}$. Seasonal average abundance for Corophium volutator exhibited a conspicuous spatial distribution, being almost (St. A, B, C, F and G) or completely (St. E) absent except for high abundance $(1,100$ ind $\mathrm{m}^{-2}$ ) at St. D. The average individual biomass of C. volutator was $0.4 \mathrm{mg} \mathrm{dw}$ at St. D. The seasonal average abundance of Macoma balthica was highest at St. B (440 ind $\left.\mathrm{m}^{-2}\right)$, intermediate at St. A, C, D, F and G (110-260 ind $\mathrm{m}^{-2}$ ) and lowest at St. E $\left(9\right.$ ind $\left.\mathrm{m}^{-2}\right)$. The average individual weight of $M$. balthica decreased gradually along the transect from $240 \mathrm{mg} \mathrm{dw}$ at St. A to $48 \mathrm{mg} \mathrm{dw}$ at St. G, except for a few large individuals (340 $\mathrm{mg} \mathrm{dw})$. Hydrobia ulvae was the most abundant species in the marsh area (39,000-61,000 ind $\left.\mathrm{m}^{-2}\right)$ compared with the mudflat area $\left(21,000-29,000\right.$ ind $\left.\mathrm{m}^{-2}\right)$. The average individual biomass of H. ulvae was $1.5-2.5 \mathrm{mg} \mathrm{dw}$ in the mudflat and $2.5-$ $3.3 \mathrm{mg} \mathrm{dw}$ in the marsh. Littorina littorea was almost absent in the mudflat (seasonal average of 12-21 ind $\mathrm{m}^{-2}$ ) but attained high abundances in the marsh area (240-350 ind $\mathrm{m}^{-2}$ ). The average individual biomass ranged from 11 to $238 \mathrm{mg} \mathrm{dw}$ with a trend for lowest values in the marsh area.

Total macrofaunal abundance was significantly higher in September than the other sampling months $(P<0.05)$. This difference was primarily caused by an overall high abundance of $H$. ulvae in both the mudflat and marsh area during September. It is worth noting that the abundance of $H$. ulvae in the mudflat was almost an order of magnitude lower in January and March compared with September (Table 2). Infaunal abundance was also higher in September than May and March $(P<0.05)$. The Shannon diversity index was generally higher in January and March compared to May and September in open mudflat, while there was not a clear trend in the marsh areas (Fig. 2).

The ordination (MDS) based on the total abundance of macrobenthos (Fig. 5a) and infauna (Fig. 5b) identified two separate faunal assemblages, one in the open mudflat and another in the $S$. anglica marsh. These groupings were independent of season, and the infauna showed a very tight grouping in the open mudflat, while epifauna showed a much less pronounced grouping compared with that of infauna (Fig. 5c). H. ulvae was generally the most important species that contributed to dissimilarity among sites as analysed by ANOSIM and SIMPER procedures.

The multivariate Spearman rank correlation between plant biomass and macrobenthic abundance was explored using the BEST (BIO-ENV) procedure (additional data are given in Online Resource, Table 4). The biomass of below-ground plant materials and macrodetritus was positively correlated with the total macrofauna abundance, while the biomass of dead below-ground plant materials alone showed high negative correlation with infaunal abundance. There was very weak correlation between epifauna abundance and any plant materials $(\rho=0.127)$. 


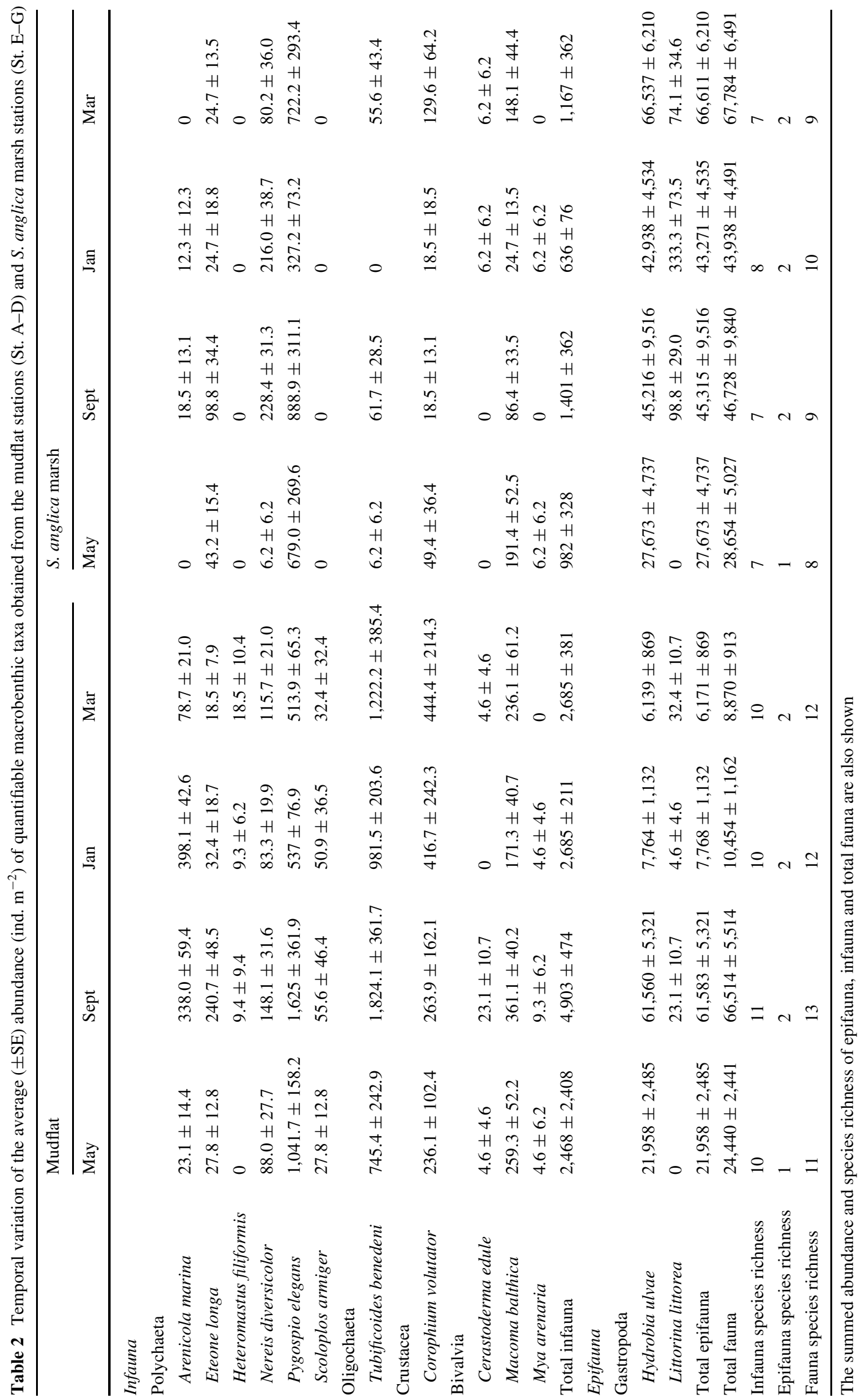




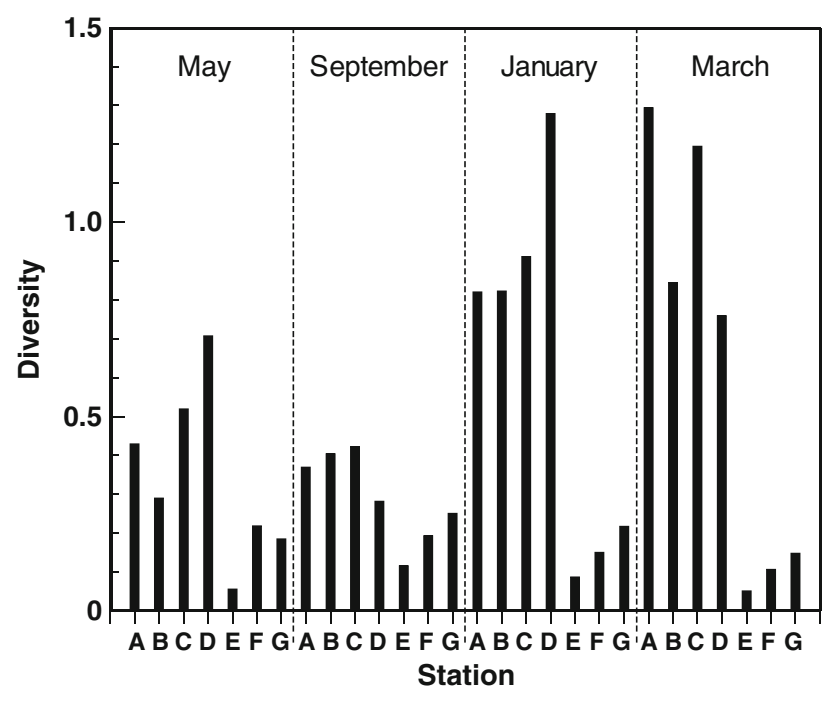

Fig. 2 Shannon diversity index at the seven stations (St. $A-G)$ during four sampling seasons

\section{Discussion}

The present study suggests a significant association between $S$. anglica with sediment and invertebrate macrobenthos assemblages. We observed three marked macrofaunal changes associated with $S$. anglica: (1) Low infaunal abundance and diversity; (2) higher abundance of epibenthic grazers and (3) high abundance of Corophium volutator at the mudflat-marsh boundary.

Associations between S. anglica and sediment properties. The key sediment properties examined here, organic content and Chl $a$ concentration, were positively related with the presence of $S$. anglica. High sediment organic content is commonly observed in saltmarsh areas and is caused by excessive deposition of fine particles (Alizai 1986).
Fallen debris from the emergent senescent plants can also be an important organic source (Gordon et al. 1985; Jackson et al. 1986). The higher Chl $a$ concentrations of the marsh area compared with the open mudflat contrast with previous reports from other vegetated saltmarsh sediments (Lana and Guiss 1992). The short and relatively open S. anglica canopy in our study area may allow sufficient light penetration for active growth of microphytobenthos. Furthermore, suspended microphytobenthos from the open flat during ingoing tides are probably deposited in the marsh vegetation during high tide slack.

Associations between Spartina anglica and macrofauna. The strong influence of invasive $S$. anglica is implied from the spatial variation in the composition of macrobenthic assemblages along the intertidal transect, particularly between the open mudflat and the marsh site. Low species richness and macrofaunal diversity are common characteristics of intertidal mudflats and saltmarshes due to extreme and variable physical and chemical conditions (Levin and Talley 2000). The macrobenthic community was, in our study area, numerically dominated by one epifauna species, $H$. ulvae, while infauna dominated in terms of species richness.

The very high density of $H$. ulvae in the vegetated areas contributed to the particularly low diversity within the marsh. A similar attraction of gastropods like H. ulvae by vegetation has been recorded in Norfolk, England (Frid and James 1989) and Arcachon Bay, France (Cottet et al. 2007). Vegetated areas are generally considered attractive to epifaunal gastropods for various reasons. These include higher food abundance and larger surface for grazing (Graça et al. 2000), damping of wave energy, physical retention of organisms floating in the water column and protection from predation (Chandrasekara and Frid 1998; Cottet et al. 2007). Increased abundance of some epifauna in mudflats during summer and decline in winter has been found
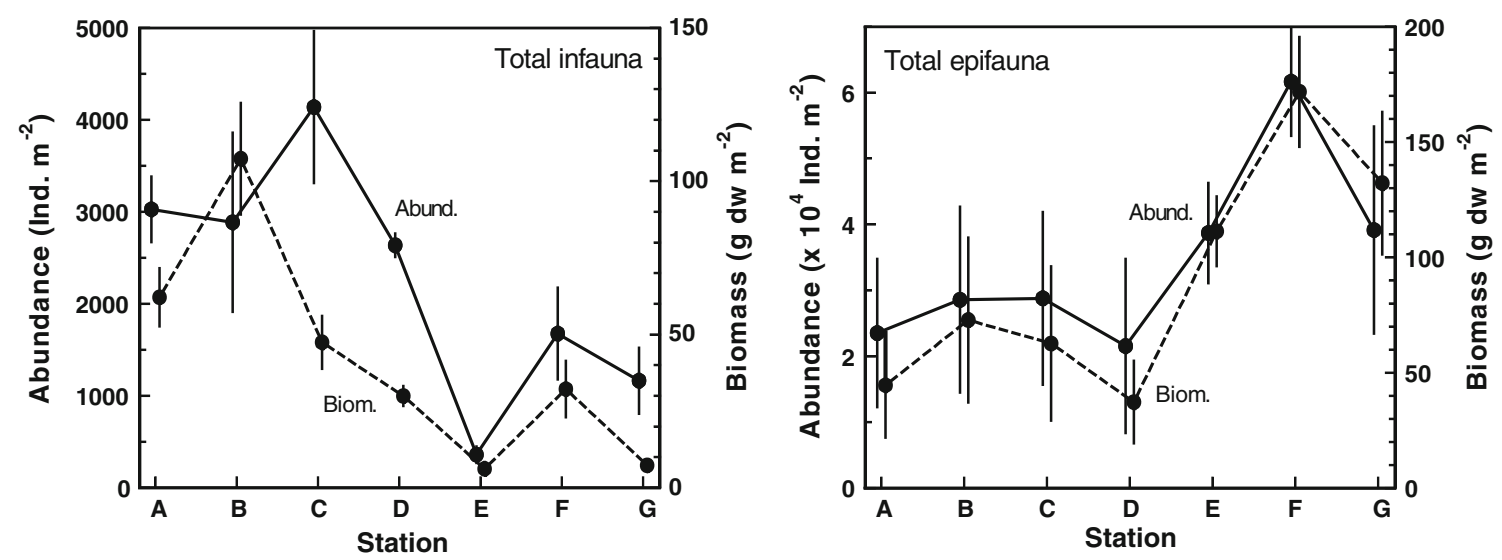

Fig. 3 Seasonal average abundance (ind $\left.\mathrm{m}^{-2}\right)$ and biomass $\left(\mathrm{g} \mathrm{dw} \mathrm{m}^{-2}\right)$ of the infauna and epifauna along the examined transect from station $A-G$. Values are given as mean $\pm \operatorname{SE}(n=4)$ 

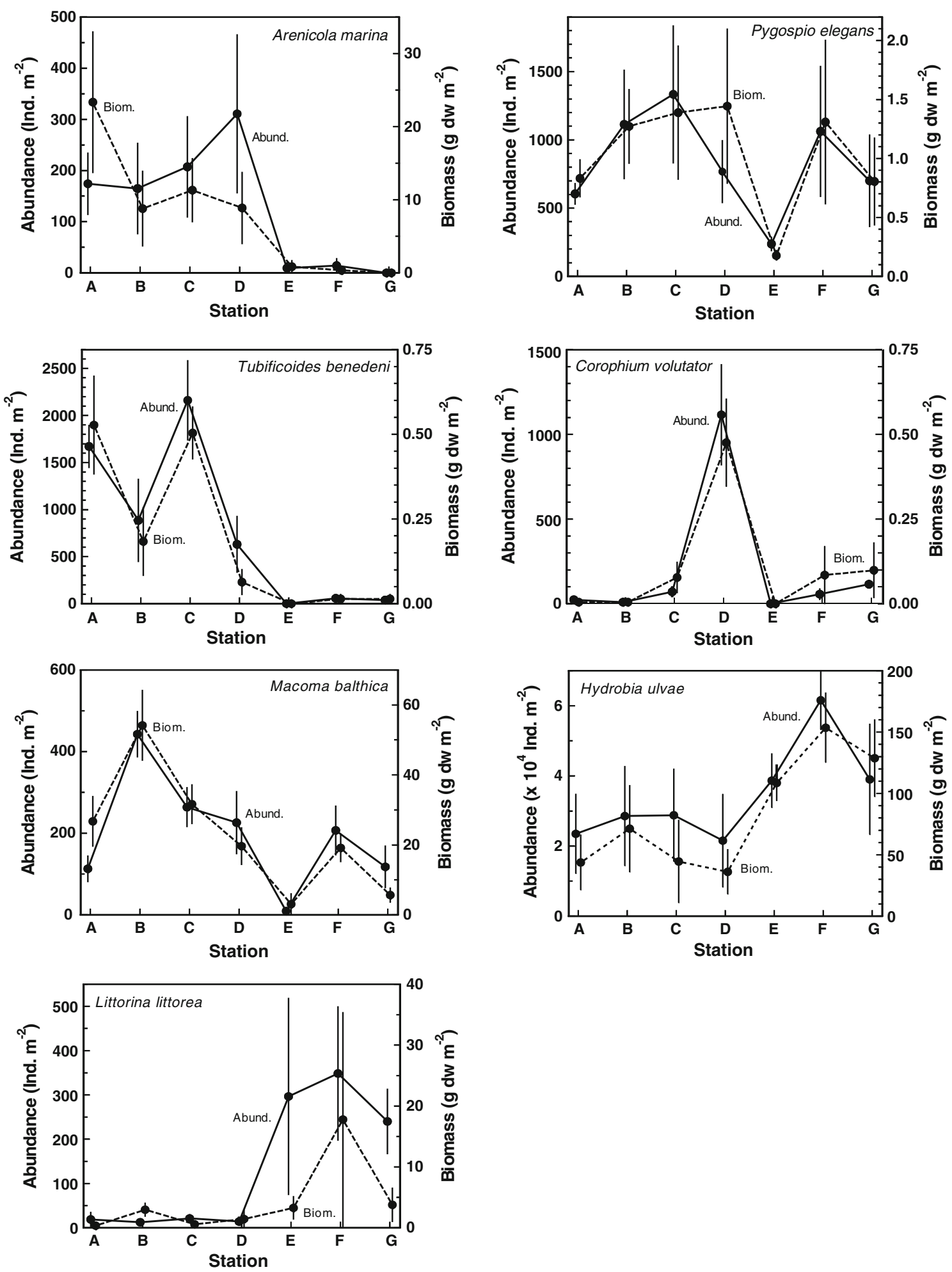

Fig. 4 Seasonal average abundance (ind $\left.\mathrm{m}^{-2}\right)$ and biomass $\left(\mathrm{g} \mathrm{dw} \mathrm{m}^{-2}\right)$ of the dominating faunal species across the transect from station $A-G$. Values are given as mean $\pm \operatorname{SE}(n=4)$

previously in the Dutch Wadden Sea and has been attributed to harsh condition in winter (Gray 1981; Zwarts and Wanink 1993). However, the absence of such pattern in the vegetated marsh area may indicate poor survival in association with growing $S$. anglica plants. It is noticeable that $H$. ulvae abundance in the mudflat decreases by almost a factor of 10 from September to March, while the abundance of this species in the marsh area at the same time 
Fig. 5 Non-metric multidimensional scaling ordinations of the abundance of macrofauna (a 2D stress: 0.15), infauna (b 2D stress: 0.15) and epifauna (c 2D stress: 0.06) in different stations in mudflat (circle) and Spartina anglica marsh (filled triangle)
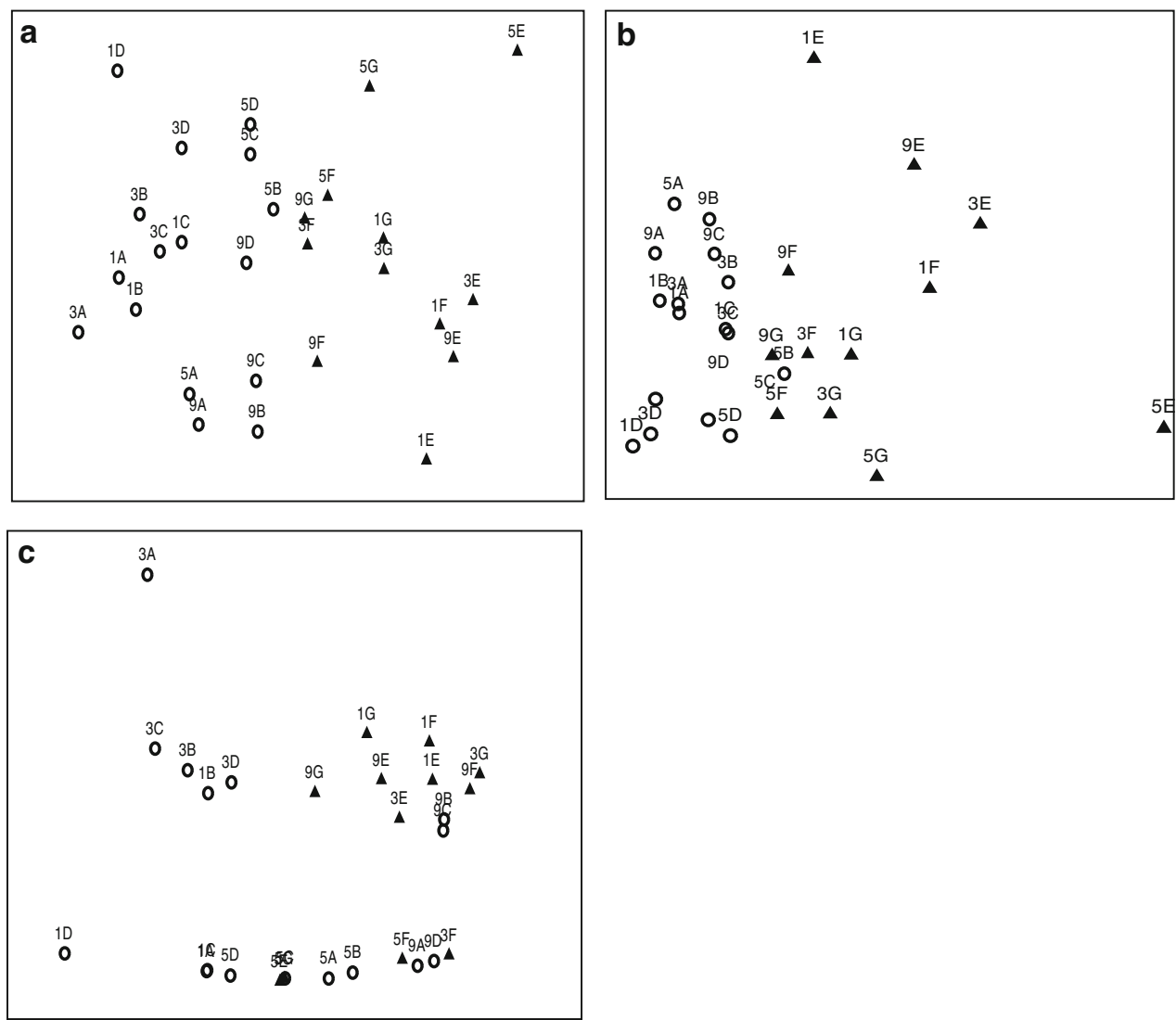

increases about 50\%. This indicates that open Wadden Sea mudflats may be particularly inhospitable during winter due to low temperatures and storm events (Beukema et al. 1993; Wilson and Parker 1996). On the other hand, the $S$. anglica marsh at the same time may provide protection and prevent sediment resuspension in both dense and sparse plant areas within marsh and therefore act as a refuge for $H$. ulvae and other epifaunal species.

The marked scarcity of infauna, such as the three burrow-dwellers, $C$. volutator, $P$. elegans and $T$. benedeni, in the marsh area and the highly negative correlation between infaunal abundance and below-ground plant biomass suggest space limitation due to occupation by densely entangled S. anglica roots/rhizomes (Brusati and Grosholz 2006). The aggregation of $C$. volutator at St. D (on average $81.6 \%$ of all individuals along the transect) is remarkable. A similar crowding of $C$. volutator near saltmarsh boundaries has been observed along other European coasts and estuaries (Jensen 1985; Hughes and Gerdol 1997; Gribsholt and Kristensen 2003). Unlike H. ulvae, C. volutator shows active habitat selection behaviour by moving around at the sediment surface during emersion and swimming in the water column during flooding (Percy 1999). Further studies are necessary to explore the reason for such $C$. volutator belt close to $S$. anglica meadows.
Indigenous macrobenthic assemblages show inconsistent responses to Spartina spp. invasions in different parts of the world. Expanding S. anglica marshes appeared hospitable for native macroinvertebrates in Little Swanport estuary, Australia (Hedge and Kriwoken 2000) and Paranagua Bay, Brazil (Netto and Lana 1999). On the other hand, negative effects similar to those observed in the present study have been reported at various locations, such as San Francisco Bay (Neira et al. 2005), southwest Netherlands (Gribsholt and Kristensen 2003) and south coast of Britain (Frid and James 1989). In many of these latter cases, the response has been attributed to differences in the below-ground plant biomass (Brusati and Grosholz 2006). However, the conflicting results from various saltmarshes make extrapolations between regions problematic due to site-specific characteristics of Spartina spp. invasions (Levin and Talley 2000).

The spreading of $S$. anglica marshes along the Wadden Sea coast may have far-reaching, and as yet not fully explored, ecological implications. The expansion of $S$. anglica may even be accelerated in the future due to global warming (Gray and Mogg 2001; Loebl et al. 2006). Danish Wadden Sea is a bird-protection area, and macroinfauna serve as important food for a variety of wading birds (Beukema et al. 1993; Zwarts and Wanink 1993; Munch-Petersen and 
Kristensen 2001). Consequently, the declined macroinfaunal abundance observed in association with S. anglica invasions may have a cascading effect on higher trophic levels and ultimately impair the overall biodiversity. It is, therefore, necessary to conduct continuous monitoring of the impact of $S$. anglica invasions on biodiversity and thus ecosystem functioning in the Danish Wadden Sea.

Acknowledgments We thank Morten Storm and Mette Marie Hansen for help with sample collection, and Ulrik Nørum, Henrik Holbech and Hans Christian Petersen for advice on statistical analyses. We are grateful to the staff of the Wadden Sea Centre for their valuable assistance and hospitality. This work was supported by a Ph.D. scholarship to MT from the International School of Aquatic Sciences and grants 645-05-0007 (MT) and 21020463 (EK) from the Danish Research Agency.

\section{References}

Alizai SAK (1986) Sediment distribution in the inertidal zone of the Tay estuary. Geol Bull Univ Pesbawar 19:33-46

Aller RC, Aller JY (1998) The effect of biogenic irrigation intensity and solute exchange on diagenetic reaction rates in marine sediments. J Mar Res 56:905-936

Beukema JJ, Essink K, Michaelis H, Zwarts L (1993) Year-to-year variability in the biomass of macrobenthic animals on tidal flats of the Wadden Sea: how predictable is this food source for birds? Neth J Sea Res 31:319-330

Brusati E, Grosholz ED (2006) Native and introduced ecosystem engineers produce contrasting effects on estuarine infaunal communities. Biol Inv 8:683-695

Chandrasekara WU, Frid CLJ (1998) A laboratory assessment of the survival and vertical movement of two epibenthic gastropod species, Hydrobia ulvae (Pennant) and Littorina littorea (Linnaeus), after burial in sediment. J Exp Mar Biol Ecol 221:191-207

Clarke KR, Ainsworth M (1993) A method of linking multivariate community structure to environmental variables. Mar Ecol Prog Ser 92:205-219

Cottet M, de Montaudouin X, Blanchet H, Lebleu P (2007) Spartina anglica eradication experiment and in situ monitoring assess structuring strength of habitat complexity on marine macrofauna at high tidal level. Estuar Coast Shelf Sci 71:629-640

Frid C, James R (1989) The marine invertebrate fauna of a British coastal salt marsh. Holar Ecol 12:9-15

Gordon DC Jr, Prouse NJ, Cranford PJ (1985) Occurrence of Spartina macrodetritus in Bay of Fundy waters. Estuaries 8:290-295

Graça MA, Newell SY, Kneib RT (2000) Grazing rates of organic matter and living fungal biomass of decaying Spartina alterniflora by three species of salt-marsh invertebrates. Mar Biol 136:281-289

Gray JS (1981) The ecology of marine sediments. Cambridge University Press, New York

Gray AJ, Mogg RJ (2001) Climate impacts in pioneer saltmarsh plants. Clim Res 18:105-112

Gribsholt B, Kristensen E (2003) Benthic metabolism and sulfur cycling along an inundation gradient in a tidal Spartina anglica salt marsh. Limnol Oceanogr 48:2151-2162

Hacker SD, Heimer D, Hellquist CE, Reeder TG, Reeves B, Riordan TJ, Dethier MN (2001) A marine plant (Spartina anglica) invades widely varying habitats: potential mechanisms of invasion and control. Biol Inv 3:211-217

Hedge P, Kriwoken ALK (2000) Evidence for effects of Spartina anglica invasion on benthic macrofauna in Little Swanport estuary, Tasmania. Aust Ecol 25:150-159
Hughes RG, Gerdol V (1997) Factors affecting the distribution of the amphipod Corophium volutator in two estuaries in south-east England. Estuar Coast Shelf Sci 44:621-627

Jackson D, Long SP, Mason CF (1986) Net primary production, decomposition and export of Spartina anglica on a Suffolk saltmarsh. J Ecol 74:647-662

Jensen KT (1985) The presence of the bivalve Cerastoderma edule affects migration, survival and reproduction of the amphipod Corophium volutator. Mar Ecol Prog Ser 24:269-277

Lana PC, Guiss C (1992) Macrofauna-plant-biomass interactions in a salt marsh in Paranagua Bay (SE Brazil). Mar Ecol Prog Ser 80:57-64

Levin LA, Talley TS (2000) Influence of vegetation and abiotic environmental factors on salt marsh invertebrates. In: Weinstein MP, Kreeger DA (eds) Concepts and controversies in tidal March ecology. Kluwer, Dordrecht, pp 661-708

Loebl M, van Beusekom EEJ, Reise K (2006) Is spread of the neophyte Spartina anglica recently enhanced by increasing temperatures? Aqu Ecol 40:315-324

Munch-Petersen S, Kristensen PS (2001) On the dynamics of the stocks of blue mussels (Mytilus edulis L.) in the Danish Wadden Sea. Hydrobiologia 465:31-43

Nehring S, Hesse K-J (2008) Invasive alien plants in marine protected areas: the Spartina anglica affair in the European Wadden Sea. Biol Inv 10:937-950

Neira C, Levin LA, Grosholz ED (2005) Benthic macrofaunal communities of three sites in San Francisco bay invaded by hybrid Spartina, with comparison to uninvaded habitats. Mar Ecol Prog Ser 292:111-126

Netto SA, Lana PC (1999) The role of above- and below-ground components of Spartina alterniflora (Loisel) and detritus biomass in structuring macrobenthic associations of Paranaguá Bay (SE, Brazil). Hydrobiologia 400:167-177

Parsons TR, Maita Y, Lalli CM (1984) A manual of chemical and biological methods for seawater analysis. Pergamon Press, Oxford

Percy JA (1999) Keystone corophium: master of the mudflats. Fundy Issues \#13. Bay of Fundy Ecosystem partnership publication, $p 12$

Reise K (2002) Sediment mediated species interactions in coastal waters. J Sea Res 48(2):127-141

Reise K (2005) Coast of change: habitat loss and transformations in the Wadden Sea. Helgol Mar Res 59:9-21

Reise K, Gollasch S, Wolff WJ (1999) Introduced marine species of the North Sea coasts. Helgol Mar Res 52:219-243

Reise K, Olenin S, Thieltges DW (2006) Are alien threatening European aquatic coastal ecosystems? Helgol Mar Res 60:106-112

Rosa S, Granadeiro JP, Vinagre C, França S, Cabral HN, Palmeirim JM (2008) Impact of predation on the polychaete Hediste diversicolor in estuarine intertidal flats. Estuar Coast Shelf Sci 78:655-664

Snelgrove PVR (1998) The biodiversity of macrofaunal organisms in marine sediments. Biod Cons 7:1123-1132

Thieltges DW, Strasser M, Reise K (2006) How bad are invaders in coastal waters? The case of the American slipper limpet Crepidula fornicata in western Europe. Biol Inv 8:1673-1680

Vinther N, Christiansen C, Bartholdy J (2001) Colonisation of Sparti$n a$ on a tidal water divide, Danish Wadden Sea. Danish J Geogr 101:11-20

Wilson WH, Parker K (1996) The life history of the amphipod, Corophium volutator: the effects of temperature and shorebird predation. J Exp Mar Bio Ecol 196:239-250

Zwarts L, Wanink JH (1993) How the food supply harvestable by waders in the Wadden Sea depends on the variation in energy density, body weight, biomass, burying depth and behaviour of tidal-flat invertebrates. Neth J Sea Res 31:44-476 